\title{
A ação e as ideias do empresariado no processo decisório da Política Nacional de Saúde
}

\author{
Action and ideas by private business leaders in the decision-making \\ process in the Brazilian National Health Policy
}

Acciones e ideas del empresariado en el proceso decisorio de la Política Nacional de Salud

EMPRESARIADO E POLÍTICAS PÚBLICAS DE SAÚDE NO BRASIL CONTEMPORÂNEO. Braga IF. Rio de Janeiro: Editora Fiocruz; 2018. p. 178. ISBN 978-85-7541-559-7.

doi: 10.1590/0102-311X00032519

O objetivo dessa obra é analisar a "natureza" e as "formas" das entidades de representação dos empresários na política nacional de saúde como forma de verificar se tais entidades incrementaram a sua organização no contexto de formulação e implementação do Sistema Único de Saúde (SUS) e se isso implicou em maior permeabilidade dos interesses privados na política nacional de saúde entre 1994 e 2010. A resposta é positiva para as duas questões.

De imediato, constata-se a importância do trabalho de Ialê Braga para as pesquisas na área de Políticas Públicas e para os estudos sobre a ação política do empresariado. Sempre serão bem-vindos estudos que contemplem os diversos setores econômicos do empresariado para além da indústria e do setor financeiro. E o caráter dramático do tema Saúde Pública, no que concerne à realidade da maior parte população brasileira, e a força econômica desse setor empresarial acrescentam ainda mais interesse à obra.

A partir das proposições de Gramsci e de Poulantzas, a autora entende os empresários que prestam serviços médico-hospitalares como "di- fusores", com "diferentes graus de consciência e organização política”, de um "novo consenso e uma nova cultura” a respeito da Política Nacional de Saúde. Por sua vez, suas entidades de representação seriam formas de elevação do "grau de autoconsciência e organização política” desses empresários. A análise se completa com a consideração das articulações dessa "visão de mundo" com a de outros setores empresariais e com o estudo dos padrões de ação política adotados por esse grupo.

Portanto, a obra contempla os eixos temáticos, com suas inevitáveis implicações teóricas, metodológicas e históricas, dos estudos sobre o empresariado, em particular, ou sobre a ação política organizada de grupos sociais, em geral, a saber: a formulação dos interesses, a construção dos valores e a definição da ação. A forma como a autora articula tais eixos torna o trabalho ainda mais interessante.

Assim, Ialê Braga enfrenta a questão do uso do marxismo enquanto Ciência Social 1, ultrapassando as caricaturas, positivas ou negativas, que, infelizmente, povoam o senso comum, a imprensa e até mesmo o meio acadêmico. Ao utilizar conceitos como classes e frações de classe, hegemonia e bloco no poder, a autora encara o desafio da sua transformação em categorias analíticas de processos históricos específicos, portanto, para além das considerações mais abstratas sobre as características gerais do modo de produção capitalista ou acerca da natureza de classe da sociedade. Mais do que heróis ou 
vilões, mesmo que esses existam, os atores e as forças que permeiam essa análise são tratados com rigor e critério, e é exatamente isso que torna a análise mais incisiva e interessante, reforçando a importância de os pesquisadores se resguardarem no campo científico e acadêmico, sem pretender a objetividade pura ou a neutralidade axiológica, mas deixando ao âmbito da política e da prática da cidadania democrática, o enfrentamento dos problemas concretos que atingem a nossa sociedade em relação à Saúde.

Adotando-se ou não esse ponto de vista teórico, não há como desconsiderar a validade do percurso de construção de uma abordagem sociológica do processo de constituição de um dado agente econômico enquanto ator político, no qual se articulam as dimensões dos interesses econômicos e das ideias e visões de mundo com a ação efetiva nos espaços institucionais.

Outro aspecto interessante, nem sempre presente nos estudos sobre o empresariado ou outros atores sociais ou institucionais, é o tratamento da relação com o Judiciário, mais particularmente, o estudo das Ações Diretas de Inconstitucionalidade (ADIs), prerrogativa das confederações sindicais patronais, que é uma das formas institucionais de organização da representação utilizada pelo empresariado do setor da Saúde. A autora mostra também como essa agenda muda e está sujeita aos conflitos internos e externos ao grupo, o que também impacta as suas formas institucionais de representação.

Enfim, esse tipo de estudo revela detalhes importantes da relação entre sociedade e Estado, mais particularmente entre um setor importante do empresariado e a democracia, dado que, de um lado, analisa as formas institucionalizadas de constituição desse setor empresarial em um ator político relevante e, de outro, a sua relação com instituições democráticas fundamentais, no caso, o Executivo, o Legislativo e o Judiciário.

Portanto, a análise dos processos relacionados ao aprendizado por parte de atores sociais relevantes em relação ao processo de definição interna e defesa externa de seus interesses no contexto da democracia é fundamental para a sua compreensão enquanto forma de funcionamento da sociedade e do Estado, seja do ponto de vista sociológico, seja do que seria o senso comum. Isso implica, por conseguinte, em uma contribuição relevante da autora para a compreensão da democracia brasileira do ponto de vista de uma Sociologia Política, ao pensar a dinâmica das instituições e da própria democracia a partir do comportamento de atores sociais relevantes em instituições políticas relevantes. Isso reforça a importância desse trabalho não só para os estudiosos e profissionais da área de Saúde ou da ação política do empresariado, ou até mesmo para aqueles que estão interessados em compreender o funcionamento e pensar no futuro da democracia brasileira.

Em relação ao empresariado do setor médico-hospitalar, esse processo de aprendizado vai desde a atuação na configuração do aparato legal relativo à saúde, passando pela constituição de entidades de representação, até o financiamento de campanha. Enfim, todos os procedimentos típicos do funcionamento das democracias nas sociedades capitalistas. Se isso, por um lado, não nos permite desconsiderar as desigualdades estruturais na capacidade de ação política que caracterizam tais sociedades, nem sermos ingênuos de pensar que as práticas na defesa de interesses empresariais se reduzem ao jogo institucional legal, por outro, não nos permite também desconsiderar que, essas práticas estão se dando no bojo de um mínimo de institucionalidade democrática.

Isso é relevante não apenas enquanto questão sociológica, mas também quando se considera a consolidação da democracia no Brasil, processo complexo e ainda em andamento. Uma das sugestões para o enfretamento da questão da Saúde no Brasil feita pela autora reforça a ideia de que somente a organização e a especialização da atuação no processo decisório permitiriam que os interesses da população, seja lá o que se entenda por isso, sejam contemplados. Ou seja, o único caminho, ao menos no que se coloca no horizonte da sociedade brasileira, seria o de procurar assumir o maior protagonismo possível no jogo político, como o fez o empresariado do setor aqui estudado.

Portanto, há contribuições importantes de Ialê Braga também para o enfrentamento dos 
problemas da sociedade, por meio de seus atores políticos organizados ou dos cidadãos em geral, o que acrescenta maior relevância e atualidade ao trabalho.

O que poderia haver de ausente no trabalho da autora advém de seus méritos, ou seja, as novas questões e frentes de pesquisa decorrentes daquilo que a autora apresenta, como, por exemplo, a realização de estudos de caso de ação empresarial no processo decisório de políticas específicas na área; explorar mais o grau de permeabilidade do Estado aos interesses desses empresários, por exemplo, junto ao Judiciário; e a verificação de eventuais diferenças nas estratégias e nas agendas das entidades sindicais (sindicatos, federações e confederações) e as associativas, bem como eventuais disputas internas e externas ao setor de Saúde.

Talvez seja ingênuo esperar que esse trabalho seja consultado pelos agentes que aqui são estudados, mas certamente seria interessante, dado que isso lhes seria útil também no sentido de pensarem e avaliarem as consequências de suas práticas e de seus valores para toda a sociedade. Sobre isso, é sempre bom lembrar o comentário de Michel Offerlé 2 sobre empresários e cientistas sociais: uns têm muita dificuldade em conhecer e compreender o que de fato os outros fazem.

Paulo Roberto Neves Costa 1

1 Universidade Federal do Paraná, Curitiba, Brasil.

paulocostaufpr@gmail.com

\section{Informação adicional}

ORCID: Paulo Roberto Neves Costa (0000-00033438-317X).

1. Codato A, Perissinotto RM. Marxismo como ciência social. Curitiba: Editora UFPR; 2011.

2. Offerlé M. Sociologie des organizations patronales. Paris: Editions La Découverte; 2009. 